\title{
Unique Combinations of Stakeholders in a Transfrontier Conservation Area Promote Biodiversity-Agriculture Integration
} \author{
0002, South Africa. \\ ${ }^{b}$ CIRAD, UR105, F-34398 Montpellier, France \\ Corresponding Author: \\ MUNYARADZI CHITAKIRA \\ Postal Address: University of Pretoria \\ Centre for Environmental Studies \\ 2.1-4 Geography Building \\ Private Bag X20 Hatfield, 0028, SOUTH AFRICA. \\ Telephone (Office): $\quad+27124204282$ \\ Cell: $\quad+27739092999$ \\ Fax: $\quad+27124203210$ \\ Email: $\quad$ mchitakira@zoology.up.ac.za
}

MUNYARADZI CHITAKIRA ${ }^{\mathrm{a}}$, EMMANUEL TORQUEBIAU $^{\mathrm{a}, \mathrm{b}}$ and WILLEM FERGUSON ${ }^{\mathrm{a}}$

${ }^{a}$ Centre for Environmental Studies, Department of Geography, GIS \& Meteorology, University of Pretoria, Pretoria

ABSTRACT

The world seeks to balance biodiversity protection and food production. Transfrontier conservation areas (TFCAs) provide unique opportunities for strategies that combine agriculture with biodiversity conservation at a landscape level, known as ecoagriculture. We identified and consulted ecoagriculture stakeholders in a smallholder farming community within a TFCA. Data were obtained through key informant interviews and questionnaire surveys. Eighty-eight percent of key informants indicated that planned ecoagriculture was feasible in the area and $95 \%$ of interviewed farmers positively considered to plan the integration of biodiversity conservation and farming. Potential conflicts of interest were revealed 
among stakeholders but to a large extent, stakeholder roles and interests were complementary, creating an environment conducive to effective coordinated ecoagriculture planning.

\section{KEYWORDS}

Stakeholder analysis, ecoagriculture landscape, transfrontier conservation areas, biodiversity conservation, livelihoods

\section{INTRODUCTION AND CONCEPTUAL FRAMEWORK}

The world is under increasing pressure to effectively protect biodiversity as a critical resource on one hand and to produce enough food for its ever-growing human population, on the other. Agriculture and biodiversity conservation have traditionally been considered antagonistic and in many countries of the world, including South Africa, industrial and smallholder farming remain separated from conservation schemes and protected areas (PAs). Conservation schemes have tended to prioritise the establishment of PAs and the preservation of specific fauna and flora species and habitats (Shames and Scherr, 2009). While such efforts are commendable, the level of protection so far attained is too low to maintain critical habitat and ecosystem services. Over $50 \%$ of all wild species exist principally outside PAs, mostly in agricultural landscapes (Millennium Ecosystem Assessment, 2005). Thus PAs alone cannot sufficiently address the challenge of biodiversity conservation.

Like other production systems such as mining and manufacturing, agriculture needs to adjust to global climate change and current environmental concerns (Pretty, 2008). Meanwhile, communal 
farming areas particularly in Sub-Saharan Africa are synonymous with poverty and deprivation (Eriksen and Watson, 2009; Triegaardt, 2006; van Oosterhout, 2005). Investing in agricultural production approaches that are compatible with prevailing social and biophysical circumstances and that simultaneously generate significant incomes for the farmers could change the fate of these communities through reducing poverty.

Literature focuses on the negative impacts of agriculture on the environment and little is said about the potential of agricultural areas to conserve biodiversity. However, agricultural landscapes have the potential to increase the efficiency of neighbouring PAs, to improve the effectiveness of biological corridors (passages of natural vegetation) cutting across unprotected areas and, to provide patches of critical habitat in uncultivated or farmer-protected areas (Shames and Scherr, 2009). This status may be achieved through production-with-protection strategies. One such strategy is ecoagriculture. Ecoagriculture refers to integrated conservation and agriculture mosaic landscapes in which biodiversity conservation is an explicit objective of agriculture and rural development (Scherr and McNeely, 2007). Ecoagriculture is a multidimensional practice whose main goals are agricultural production, biodiversity conservation, livelihoods improvement and institutional coordination (Buck, et al., 2006). It is implemented at the landscape level extending beyond the individual farm or single project level. A 'landscape' is a cluster of local ecosystems characterized by a particular configuration of topography, vegetation, land use, and settlement (Scherr et al., 2011). The functionality of many ecosystem services emerges at the landscape level (Perfecto et al., 2009) and for ecoagriculture to make an impact the elements of the landscape should be considered as a whole. The goal to maintain biodiversity and ecosystem services, manage agricultural production sustainably and contribute 
to improved rural livelihoods cannot be achieved at a mere farm or plot level, but are linked at the landscape scale (Scherr et al., 2011). Different parts of a landscape may provide food, fuel, water, pollination or pest control functions. Mosaics or patches of land cover and land uses that make up an ecoagriculture landscape include crop fields, pastures, forests, protected areas, corridors, wetlands and ecological infrastructures such as hedges or terraces (Ecoagriculture Partners and IUCN, 2007; Scherr and McNeely, 2008). Environmental and production functions are optimised by managing such different units in a complementary way (Sayer and Campbell, 2004; Lindenmayer et al., 2008) for the simultaneous well-being of people and the environment.

The present work is part of a broader study that seeks to promote ecoagriculture in a smallholder farming community located in a Transfrontier Conservation Area (TFCA). TFCAs are natural ecosystems that cross political boundaries between two or more countries and include one or more protected areas and multiple resource use areas (SADC, 1999). Their main purpose is conservation and sustainable use of biological and cultural resources, whilst promoting regional peace, co-operation and socio-economic development (Sandwith et al., 2001). This purpose coincides with ecoagriculture goals. Ecoagriculture innovations present opportunities for achieving the TFCA purpose and are therefore expected to be attractive to communities in or around TFCAs. The present study recognises smallholder or communal farmers as fundamental biodiversity stewards and top-priority beneficiaries of conservation initiatives. The study believes that the farmers along with other key stakeholders must be actively engaged in planning and managing resources in their locality. Participatory decision-making creates a sense of ownership and greater commitment to project goals resulting in more sustainable management (Evans et al., 2006; Nemarundwe et al., 2003; Ecoagriculture Partners, 2008a). Local laypersons 
have intimate knowledge of their surroundings and how they have changed over the years (Buck et al. 2006). Involving local communities therefore utilises the wealth of indigenous knowledge systems and practices. These observations motivated stakeholder engagement in the current study.

Stakeholder analysis (SA) is a pre-requisite of stakeholder engagement. SA is a process of systematically gathering and analysing qualitative information to determine whose interests should be taken into account when developing or implementing a policy or programme (Schmeer, 2000). In natural resources management, SA implies the procedures for identifying who has a stake in a particular resource, assessing their interests and roles and establishing their opinions regarding a proposed project. SA helps to identify present or future opportunities and threats to projects (Blair and Fottler, 1990). In the present study, SA was expected to yield information that would guide the ensuing stages of the broader study as well as to reveal prospects of ecoagriculture planning and implementation in the study area. SA would also provide deeper insights into the area's socio-economic and institutional landscape as well as produce information useful to facilitators of ecoagriculture projects.

The objectives of this study were to identify key stakeholders with regards to the possible development of an ecoagriculture landscape in a smallholder farming community within a TFCA, to assess the roles and interests of the stakeholders and to establish their perceptions regarding the feasibility of systematic ecoagriculture in the area. An underlying assumption was that the existing socio-economic, biophysical and policy conditions were conducive to sustainable stakeholder-driven ecoagriculture landscape management. 


\section{STUDY AREA CHARACTERISTICS}

The study was conducted in the Mathenjwa Tribal Authority (MTA), a communal farming area in northern KwaZulu-Natal Province of South Africa $\left(26^{\circ} 48^{\prime} \mathrm{S}\right.$ to $26^{\circ} 57^{\prime} \mathrm{S}$ and $32^{\circ} 00^{\prime} \mathrm{E}$ to $\left.32^{\circ} 10^{\prime} \mathrm{E}\right)$. The area covers approximately $547 \mathrm{~km}^{2}$ of which $19 \%$ is within the Ndumo Game Reserve managed by a provincial nature conservation body, Ezemvelo KwaZulu-Natal Wildlife. A further $6.4 \%$ is allocated to the Usuthu Gorge Community Conservation Area (CCA), a conservancy managed by the local community.

The MTA falls into the subtropical savanna biome (Mucina and Rutherford, 2006) with an annual rainfall between $500 \mathrm{~mm}$ in the eastern lowlands (around $100 \mathrm{~m} \mathrm{ASL}$ ) and $800 \mathrm{~mm}$ in the western plateau (about $600 \mathrm{~m}$ ASL). Most of the rainfall is received in summer from November to March but light rains are occasionally received during winter. The mean annual temperature is around $21^{\circ} \mathrm{C}$ with summer maximum reaching $40^{\circ} \mathrm{C}$. Thus the area is generally dry and warm to hot throughout the year.

The MTA lies in Maputaland Centre which is an ecological region characterised by endemic flora and also a globally recognised biodiversity hotspot (Van Wyk and Smith, 2001). It is therefore important to conserve the biodiversity of this area which harbours many endemic plants and some of the most endangered vegetation types in South Africa, classified as vulnerable (Mucina and Rutherford, 2006). The MTA became part of the Lubombo TFCA (Figure 1) after South Africa, Mozambique and Swaziland signed a trilateral protocol in 2000 (SADC, 2006). 


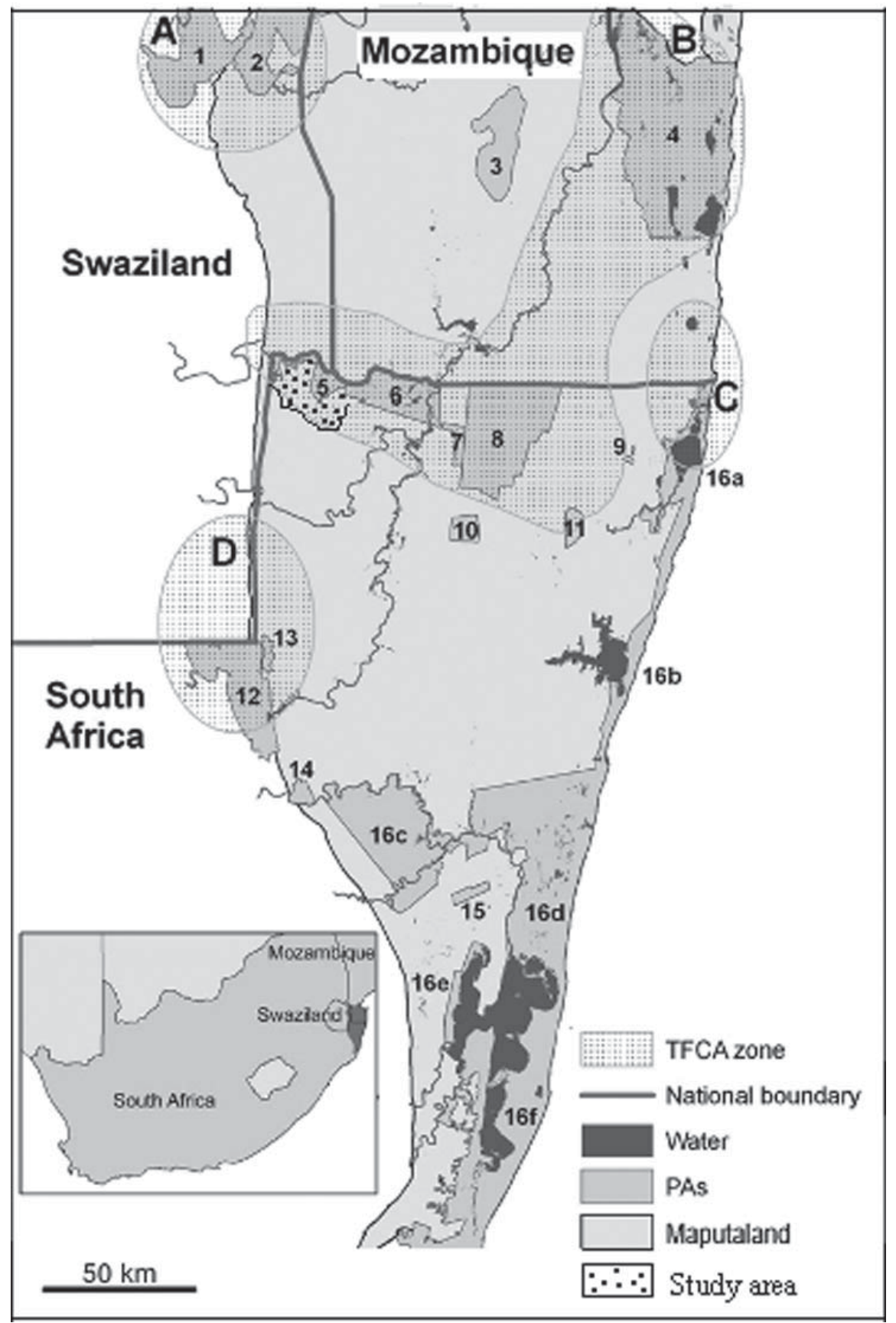

FIGURE 1 Study area (modified from Smith et al. 2008). Key: TFCA zones are labeled alphabetically and PAs are labeled numerically: A = Lubombo-Goba, B = Usuthu-Tembe-Futhi, C = Kosi Bay-Ponta do Ouro, D = Nsubane-Pongola; $5=$ Usuthu Gorge Community Conservation Area, $6=$ Ndumo Game Reserve (GR), 7 = Bhekabantu CCA, $8=$ Tembe Elephant Park.

The inhabitants of Maputaland are among southern Africa's poorest people who have traditionally depended significantly on harvesting natural resources (Soto et al., 2001). The MTA is one of the many rural areas of South Africa that lack access to basic services and infrastructure 
essential for economic growth and development (Herselman, 2003; Jozini Local Municipality, 2009). Unemployment and poverty levels in the area are high. The poor community members put biodiversity under threat as they strive to make a living. In order to achieve the aims of the TFCA there is thus a need to foster conservation strategies in the area but without compromising local livelihoods.

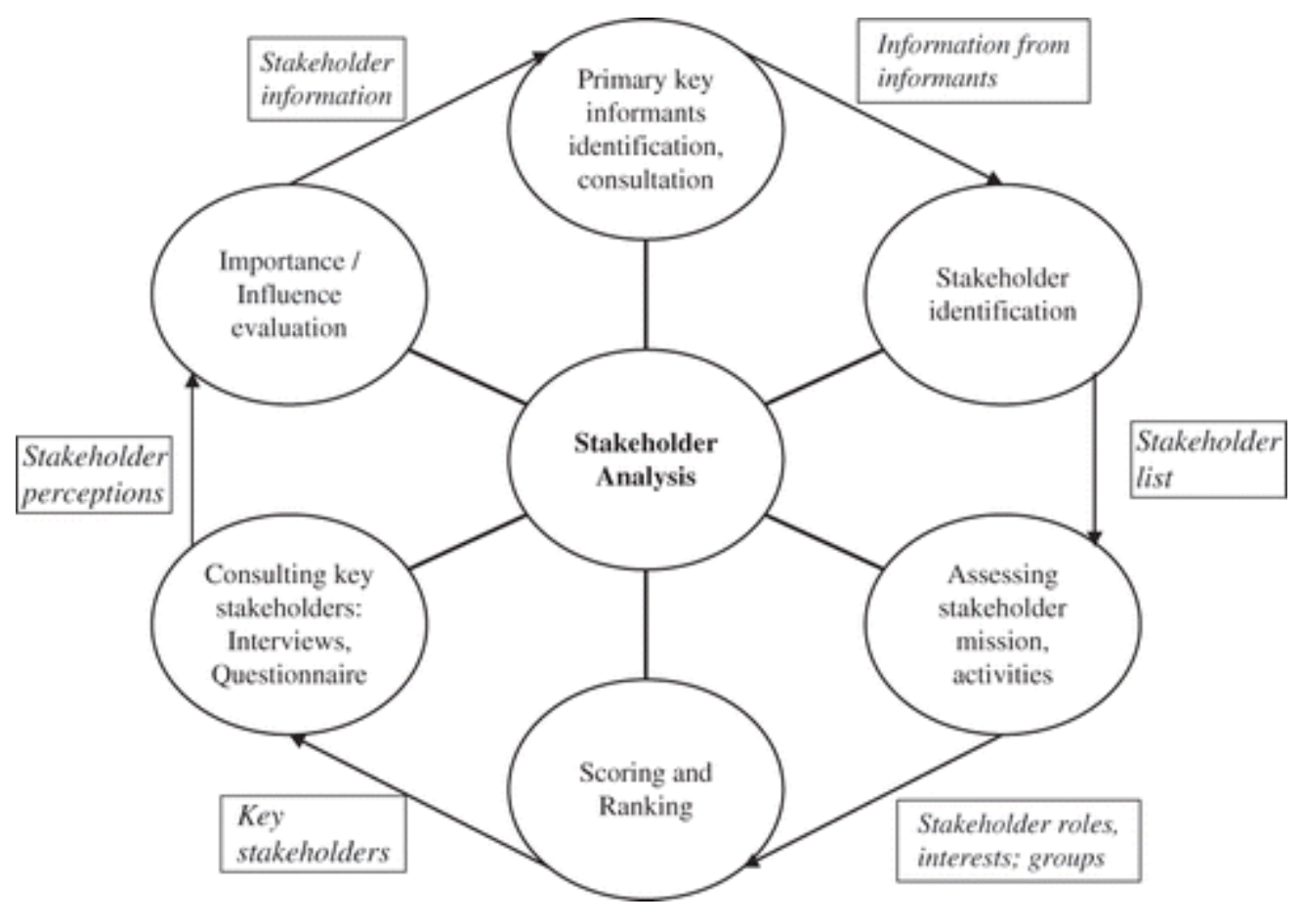

FIGURE 2 Procedures taken during stakeholder analysis process.

\section{METHODS}

Different approaches can be used for conducting SA and there is no blueprint to this regard (Grimble, 1998). The present study employed information from informants as a tool to identify stakeholders and establish their roles and interests. The SA process involved several stages from the identification of primary key informants up to stakeholder importance-influence determination as illustrated in Figure 2. Outputs from each stage are shown in the adjacent boxes. 
Five primary key informants (including three local community members and two professionals) knowledgeable about the MTA were consulted. A stakeholder analysis matrix was used to capture information provided. These informants were asked three basic questions: (i) who needs to be involved to get ecoagriculture implemented? (ii) who can prevent progress towards this goal? (iii) who will be affected as this goal becomes realised? They were then asked to indicate as individuals the "impact" of each stakeholder by awarding a score ranging from 1 (minor) to 3 (major). "Impact" was interpreted to mean the extent to which a stakeholder's presence or activities were being felt in the community. Total scores for each stakeholder were used to rank the stakeholders to determine key players. Secondary data sources including official reports, newsletters, mission statements and websites were consulted to obtain more information on the stakeholders' roles and interests.

Stakeholder consultation was achieved through 17 semi-structured key informant interviews with selected representatives of the identified key stakeholder institutions and, 170 questionnaire interviews with randomly selected farmers' household heads. To ensure that respondents had a common understanding of what ecoagriculture involves and thus improve the reliability of responses, the ecoagriculture concept was explained and illustrated prior to each interview. The responses were recorded on the questionnaire and later processed using the IBM Statistical Package for the Social Sciences (version 17.0, Johannesburg, South Africa).

\section{RESULTS AND DISCUSSION}

Ecoagriculture Stakeholders and their Interests 
Institutions with a stake in the socio-economic and biophysical aspects of the MTA were identified as ecoagriculture stakeholders. Table 1 presents a list of all the stakeholders identified, ranked based on total scores assumed. Further information about these stakeholders is provided in the Appendix.

Three institutions appear on the highest rank. The Mathenjwa Tribal Authority was the local governing body headed by the Inkosi (Chief) and responsible for controlling access to natural resources and the day-to-day running of the community. Ezemvelo KwaZulu-Natal Wildlife was the Provincial Government agency responsible for maintaining wilderness areas and public nature reserves in KwaZulu-Natal province. Its impact was mainly felt through funding development projects like building schools in the community area, besides raising awareness and enforcing provincial conservation policies. The Wildlands Conservation Trust was a nongovernmental organisation instrumental in the establishment of the local Usuthu Gorge CCA and it supported the community by providing borehole water, vegetable seed and fencing material. These key stakeholders together with local communal farmers (next in rank) should be expected to have the most decisive influence on ecoagriculture planning and implementation.

In general, stakeholders that were more directly involved in biodiversity conservation and farming ranked higher than those less directly involved. However, there were exceptional cases where stakeholders were rated lower or higher than expected, considering their link with ecoagriculture. Tourists for instance, were rated high most probably because the informants perceived a high tourism potential for the study area. The Department of Agriculture ranked fairly low probably due to limited extension services offered to the community by this 
TABLE 1 Stakeholder analysis matrix for Mathenjwa community

\section{Stakeholder Name}

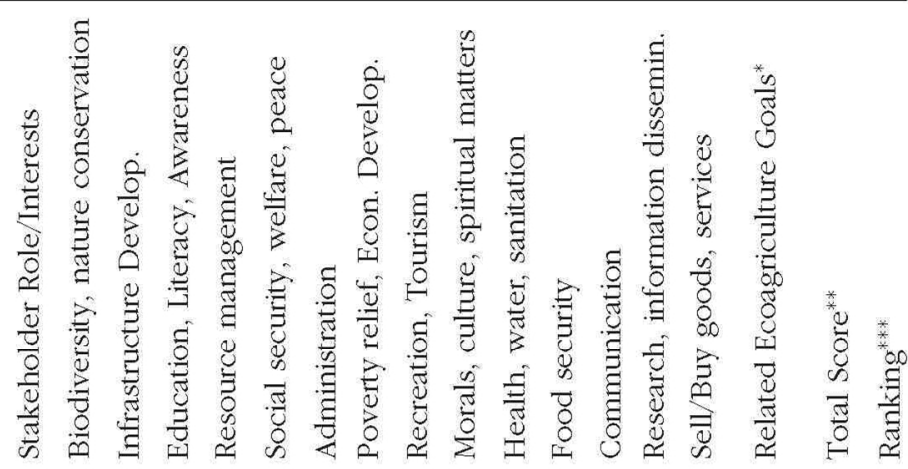

\begin{tabular}{|c|c|c|c|c|c|c|c|c|c|c|c|c|c|c|c|c|c|}
\hline 1 & Mathenjwa T. Authority & $\mathrm{x}$ & & & $\mathrm{x}$ & $\mathrm{x}$ & $\mathrm{x}$ & & & $\mathrm{x}$ & & & & & $\mathrm{p}, \mathrm{c}, \mathrm{l}$ & 14 & 1 \\
\hline 2 & Ezemvelo KZN Wildlife & $\mathrm{x}$ & $\mathrm{x}$ & $\mathrm{x}$ & $\mathrm{x}$ & & & $\mathrm{x}$ & $\mathrm{x}$ & & & & $\mathrm{x}$ & & $c, 1$ & 14 & 1 \\
\hline 3 & Wildlands C. Trust & & $\mathrm{x}$ & & & & & $\mathrm{x}$ & & & $\mathrm{x}$ & & $\mathrm{x}$ & & $c, 1$ & 14 & 1 \\
\hline 4 & Communal Farmers & $\mathrm{x}$ & & & $\mathrm{x}$ & & & & & & & & & $\mathrm{x}$ & $\mathrm{p}, \mathrm{c}, \mathrm{l}$ & 13 & 2 \\
\hline 5 & Environmental Affairs & $\mathrm{x}$ & $\mathrm{x}$ & & $\mathrm{x}$ & & & $\mathrm{x}$ & $\mathrm{x}$ & & & & & & c & 13 & 2 \\
\hline 6 & Tourists & $x$ & & & & & & & $\mathrm{x}$ & & & & & $\mathrm{x}$ & c & 13 & 2 \\
\hline 7 & Jozini Municipal LED & $\mathrm{x}$ & $\mathrm{x}$ & $\mathrm{x}$ & & $\mathrm{x}$ & $\mathrm{x}$ & $\mathrm{x}$ & $\mathrm{x}$ & $\mathrm{x}$ & & & $\mathrm{x}$ & & $c, 1$ & 12 & 3 \\
\hline 8 & Health Dpt. & & & $\mathrm{x}$ & & & & & & $\mathrm{x}$ & & & & & $\mathrm{n}$ & 12 & 3 \\
\hline 9 & Maputaland DIC & & $\mathrm{x}$ & $\mathrm{x}$ & & $\mathrm{x}$ & & $\mathrm{x}$ & & & $\mathrm{x}$ & & $\mathrm{x}$ & & 1 & 12 & 3 \\
\hline 10 & Peace Parks Foundation & $\mathrm{x}$ & $\mathrm{x}$ & & $\mathrm{x}$ & & & & $\mathrm{x}$ & & & & $\mathrm{x}$ & & $c, 1$ & 12 & 3 \\
\hline 11 & SAPS Ndumo & & & $\mathrm{x}$ & & $\mathrm{x}$ & & & & & & & & & $\mathrm{n}$ & 11 & 4 \\
\hline 12 & Agriculture Dpt. & & $\mathrm{x}$ & $\mathrm{x}$ & & & & $\mathrm{x}$ & & & $\mathrm{x}$ & & $\mathrm{x}$ & $\mathrm{x}$ & $\mathrm{p}, 1$ & 11 & 4 \\
\hline 13 & Elephant Coast & & & & & & & & $\mathrm{x}$ & & & & $\mathrm{x}$ & $\mathrm{x}$ & $\mathrm{c}, \mathrm{l}$ & 11 & 4 \\
\hline 14 & Transport Dpt. & & $\mathrm{x}$ & & & & & & & & & $\mathrm{x}$ & & & $\mathrm{n}$ & 11 & 4 \\
\hline 15 & Housing Dpt. & & $\mathrm{x}$ & & & $\mathrm{x}$ & & & & & & & & & $\mathrm{n}$ & 10 & 5 \\
\hline 16 & $\begin{array}{l}\text { Telkom, Vodacom, } \\
\text { MTN, Cell-C }\end{array}$ & & $\mathrm{x}$ & & & & & & & & & $\mathrm{x}$ & & $\mathrm{x}$ & $\mathrm{n}$ & 10 & 5 \\
\hline 17 & Local Churches & & $\mathrm{x}$ & $\mathrm{x}$ & & $\mathrm{x}$ & & & & $\mathrm{x}$ & & & & & $\mathrm{n}$ & 10 & 5 \\
\hline 18 & Education Dpt. & & & $\mathrm{x}$ & & & & & & $x$ & & & $\mathrm{x}$ & & $\mathrm{n}$ & 10 & 5 \\
\hline 19 & Researchers/Academics & & & $\mathrm{x}$ & & & & & & & & & $\mathrm{x}$ & & $\mathrm{n}$ & 10 & 5 \\
\hline 20 & Social Welfare Dpt. & & & & & $\mathrm{x}$ & & $\mathrm{x}$ & & & & & & & 1 & 9 & 6 \\
\hline 21 & Water Affairs Dpt. & & $\mathrm{x}$ & & & & & & & $\mathrm{x}$ & & & & & 1 & 9 & 6 \\
\hline 22 & Ingonyama Trust & & & & $\mathrm{x}$ & $\mathrm{x}$ & $\mathrm{x}$ & & & & & & & & $c, 1$ & 9 & 6 \\
\hline 23 & WWF & $\mathrm{x}$ & & & & & & & & & & & $\mathrm{x}$ & & c & 9 & 6 \\
\hline 24 & Eskom & & $\mathrm{x}$ & & & & & & & & & & & $\mathrm{x}$ & $\mathrm{n}$ & 9 & 6 \\
\hline 25 & Local Entrepreneurs & & & & & & & $\mathrm{x}$ & & & & & & $\mathrm{x}$ & $\mathrm{p}, 1$ & 8 & 7 \\
\hline 26 & Sport \& Recreation Dpt. & & $\mathrm{x}$ & & & & & & $\mathrm{x}$ & & & & & & 1 & 8 & 7 \\
\hline 27 & Fire fighters & $\mathrm{x}$ & & & & $\mathrm{x}$ & & & & & & & & & c & 8 & 7 \\
\hline
\end{tabular}

${ }^{*} \mathrm{p}=$ production, $\mathrm{c}=$ biodiversity conservation, $\mathrm{l}=$ viable local livelihoods, $\mathrm{n}=$ neutral

** Scores to each stakeholder were added up to give a total score.

${ }^{* * *} 1$ is the highest rank and corresponds to the highest total score of 14 . 
department. Interviews revealed a critical shortage of extension officers in the local municipality and the available officers could at most visit the community once a month. The support of the Department of Agriculture would be critical for any ecoagriculture initiative such that a shortage of extension workers is a matter of concern. The Ingonyama Trust which assumed the secondlowest rank was the legal owner of 2.8 million hectares of land in the province, including the MTA (Ingonyama Trust Board, 2004). The general perception in the community was that land belonged to the local Inkosi, thus the Trust's influence was not felt in the community. It needs to be noted, however, that stakeholders that were rated low should still be considered significant because of their potential influence on local livelihoods, biodiversity and agricultural production.

\section{Conflict of Interest}

Stakeholders can share common concerns about local natural resources but conflicts of interest may exist among them (Bellefontaine et al., 2002). The present study revealed potential conflicts that would require the attention of ecoagriculture extension agents. Tension existed between conservation authorities (like Ezemvelo KZN Wildlife) and the local community. Locals gave livelihoods the first priority and were not amused with conservation agents whom they perceived as prioritising conservation at the expense of livelihoods. Local traditional healers, for instance, were unhappy about restrictions on the use of medicinal plants that were protected by legislation. Section 57 (1) of the National Environmental Management: Biodiversity Act No. 10 of 2004 states, "A person may not carry out a restricted activity involving a specimen of a listed threatened or protected species without a permit issued in terms of Chapter 7". The process of obtaining the permit was bureaucratic, cumbersome and therefore disliked by the community. 
Conflict of interest also existed between the Ingonyama Trust Board and land users, particularly entrepreneurs and land developers. Private land users wanted title deeds as a form of collateral security for getting loans from financial institutions but the Trust could not issue title deeds but issued renewable land leases of up to 40-years. Interviews with representatives of the Trust revealed that giving title deeds was tantamount to taking land away from the king. In the Zulu culture the king's authority was vested in the land and losing land meant losing authority and power.

The study revealed few and mild cases of conflicts of interest. Table 1 and the Appendix show that the roles and interests of the stakeholders were complementary to a large extent and mainly aimed to improve the wellbeing of the local people and biodiversity. A harmonious institutional environment is vital for the promotion of ecoagriculture in the area because ecoagriculture planning requires a high degree of institutional coordination involving negotiation, implementation, resource mobilisation and capacity-building in support of ecoagriculture objectives (Buck et al., 2006). The desired coordination may not be possible unless there is harmony among institutions.

\section{Stakeholder Classification}

In our analysis we relate each stakeholder's major interests to ecoagriculture goals which include production (p), biodiversity conservation (c) and viable local livelihoods (l) as shown in Table 1. Stakeholders whose interests are not directly related to an ecoagriculture goal are labelled neutral (n). We find that the largest proportion (36\%) of stakeholder interests relate to the livelihood goal implying that stakeholders' efforts were mainly targeted at improving living standards in the 
community. Almost a third (or 31\%) of the interests relate to conservation. This is a considerable proportion and reflects the importance of biodiversity conservation in the TFCA community. Ten percent of the interests relate to production. This is relatively low considering that farming is the primary occupation in communal areas in Southern Africa. A low interest in farming can be interpreted as an indication of the area's low agricultural production potential (Jozini Local Municipality, 2009). Hence there is need for the farmers to diversify livelihoods by investing in non-agricultural enterprises.

The proportion of stakeholders' interests prioritising livelihoods, conservation and production was probably influenced by the composition of the stakeholder institutions that were consulted and analysed. However, these results represent a substantial cross-section of the nature of interests of ecoagriculture stakeholders to the entire TFCA community.

Stakeholder classification is necessary for ecoagriculture planning as it guides facilitators to identify institutions to invite for ideas, skills, equipment, infrastructure development and other contributions. The 'neutral' stakeholders still need to be considered since they can influence ecoagriculture even indirectly. For instance, a good healthcare system is important to support a healthy labour force required for the successful implementation of new initiatives.

\section{Importance-Influence Determination}

The determination of stakeholders' importance and influence is a subjective process based on perceptions of the individuals doing the analysis. However, the process is a useful step in ecoagriculture planning which is dependent on the participation of multiple players. Knowing the 
potential that stakeholders have to influence a development project helps to identify the relative risks posed by these stakeholders and potential coalitions (ICRA, c.2001).

\begin{tabular}{|c|c|c|}
\hline$\uparrow$ & $\begin{array}{l}\text { C } \\
\text { Low Importance } \text { - High Influence } \\
\text { - Ezemvelo KZN Wildlife } \\
\text { - Ingonyama Trust } \\
\text { - Local Entrepreneurs } \\
\text { - Maputaland Development \& } \\
\text { Information Centre } \\
\text { - Peace Parks Foundation } \\
\text { - Researchers/ Academics } \\
\text { - Mathenjwa Tribal Authority } \\
\text { - World Wildlife Fund (WWF) } \\
\text { Total: } 8(=30 \%)\end{array}$ & $\begin{array}{l}\text { A } \\
\text { High Importance - High Influence } \\
\text { - Agriculture Department } \\
\text { - Communal Farmers } \\
\text { - Environmental Affairs } \\
\text { - Jozini Municipal LED } \\
\text { - Water Affairs Department } \\
\text { - Wildlands Trust }\end{array}$ \\
\hline 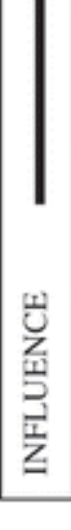 & $\begin{array}{l}\text { D } \\
\text { Low Importance - Low Influence } \\
\text { - Education Department } \\
\text { - Eskom } \\
\text { - Fire fighters } \\
\text { - Health Department } \\
\text { - Housing Department } \\
\text { - Local Churches } \\
\text { - SAPS Ndumo } \\
\text { - Social Welfare Department. } \\
\text { - Sport \& Recreation Department } \\
\text { - Telkom, Vodacom, MTN, Cell-C } \\
\text { Total: } 10(=37 \%)\end{array}$ & $\begin{array}{l}\text { B } \\
\text { High Importance - Low Influence } \\
\text { - Elephant Coast } \\
\text { - Tourists } \\
\text { - Transport Department }\end{array}$ \\
\hline
\end{tabular}

IMPORTANCE

FIGURE 3 Stakeholder positions in importance-influence matrix.

A two-by-two matrix (Figure 3) modelled after the Department of Sustainability and Environment (2008), the International Centre for development oriented Research in Agriculture (ICRA) (c.2001) and Schmeer (2000) is used to determine the importance and influence of each stakeholder institution identified in this study. 'Importance' is the priority given by projects to satisfy a stakeholder's needs and interests while 'influence' implies the power of a stakeholder to make decisions about a project, to facilitate the implementation process or, to exert influence that affects the project either positively or negatively (ICRA, c.2001). We regard the stakeholders 
whose interests align with ecoagriculture goals to be of high importance, i.e., those upon which ecoagriculture projects place great priority in satisfying whose needs, interests and expectations. To determine influence we consider the stakeholder's possession of specialist knowledge required in ecoagriculture implementation, potential administrative control, political authority, control of strategic resources and the ability to mobilise these resources for ecoagriculture projects. For instance, possession of required specialist knowledge implies high influence.

In Figure 3, the highest percentage (37\%) of the stakeholders are on position D, 30\% on C, $22 \%$ on A and the least (11\%) on B. Stakeholders in position A have a high degree of influence on ecoagriculture and are of a high importance for its success. In the present study, local farmers are of high importance and high influence (position A) reflecting the characteristics of a process dependent on participatory decision-making. This is contrary to the mainstream thinking which considers communal or peasant farmers to be of high importance but low influence, i.e. position B (Department of Sustainability and Environment, 2008). Communal farmers are often not consulted in decision making and development of policies that affect natural resources in their locality (Evans et al., 2006). Unlike donor-driven projects, ecoagriculture must be understood as a community-driven programme (CDP) centred upon and run by local farmers. In CDPs communities have much greater freedom and flexibility to make their own decisions in managing and allocating resources than in usual community based natural resource management programmes (CBNRMPs) (The World Bank, 2002). The farmers are the intended beneficiaries (high importance) and their interests must be protected. Ecoagriculture planning facilitators should create good working relationships with the stakeholders in position A to ensure their effective engagement and contribution. 
Stakeholders in position B are of a high importance to the success of ecoagriculture but they do not have much voice in its development. For instance, the interests of the Department of Transport may not be directly related to ecoagriculture goals but a viable transport service is crucial to the success of ecoagriculture through facilitating access to inputs and markets for produce or making the community accessible to tourists.

Interests of stakeholders in position $\mathrm{C}$ may not necessarily align with ecoagriculture goals but can significantly affect ecoagriculture implementation and thus need to be strategically engaged. For example, ecoagriculture planning in the community might not proceed without the approval of Mathenjwa Tribal Authority, the local traditional leadership. Stakeholders in position D are somewhat distanced from ecoagriculture and may require limited attention. However, their strategic involvement is necessary because institutional coordination is essential for ecoagriculture success. With respect to the Department of Education, for example, facilities at the local schools might be utilised for ecoagriculture skills-training workshops.

Stakeholder importance-influence determination thus helps ecoagriculture facilitators to identify appropriate stakeholders to engage at each stage of the planning process. The facilitators should build good working relationships with stakeholders of high influence and high importance to ensure an effective coalition of support (ICRA, c.2001). Our influence-importance analysis has revealed traits that differ in certain respects from those applying to rural development initiatives without participatory decision making (Grimble, 1998). Different approaches are thus required when dealing with ecoagriculture. 


\section{Stakeholders' Perceptions}

The study sought to evaluate stakeholders' perceptions on the feasibility of planned ecoagriculture in the MTA. Key informants were asked the question, "Considering the existing socio-economic and environmental conditions like policy, land tenure, climate, wildlife, soils, terrain, vegetation and household income levels, how feasible is systematic (or planned) ecoagriculture in the area?" Table 2 summarises the responses obtained.

Responses which indicated that systematic ecoagriculture was feasible are marked positive $(+)$ while those indicating that it was not feasible are labelled negative (-). Some stakeholders were not sure whether it was feasible or not and these responses are marked neutral (n). Others expressed that the proposed initiative was possible provided certain conditions were met and such responses are marked as positive on condition " $+\mathrm{c}$ ". Responses marked "+" and "+c" make up $88 \%$ of total responses. Thus a greater proportion of interviewed stakeholders perceived that it was possible and appropriate to initiate systematic ecoagriculture in the area. A questionnaire survey revealed that $51 \%$ of the farmers perceived that planned ecoagriculture had a good chance of success in the area; $14 \%$ perceived the chance as low, while $35 \%$ were neutral. Overall, key stakeholders, including local farmers (the intended beneficiaries as well as biodiversity stewards) perceived ecoagriculture being largely feasible and appropriate to the area. Predominant positive perceptions among stakeholders brighten the prospects of promoting the proposed initiative in the community. 


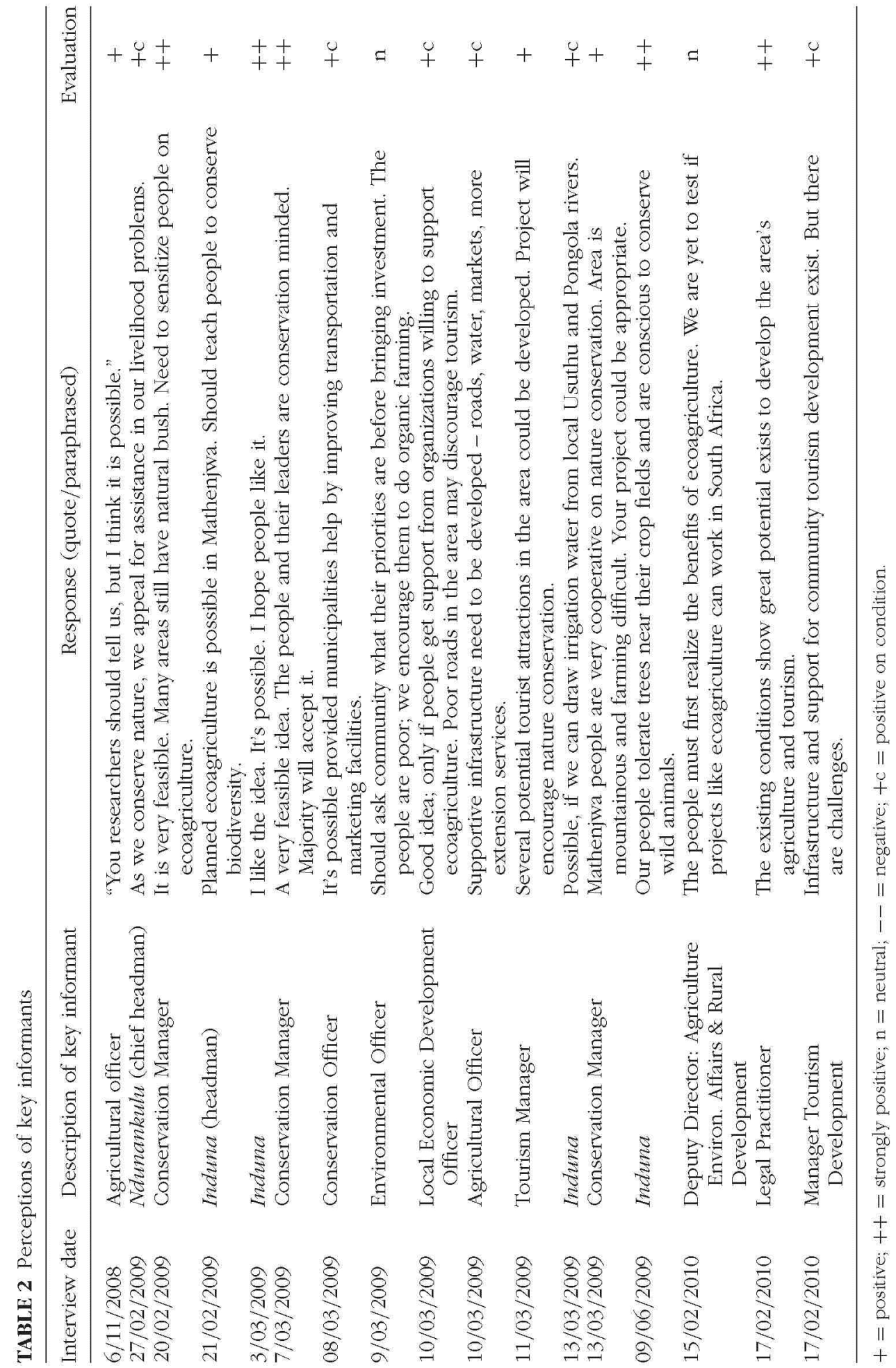


The success of a project depends on the consent and participation of its stakeholder community (Bourne, 2008). Based on this premise, the present study investigated the willingness of local farmers to participate in ecoagriculture planning. The question asked was, "Would you be willing to take part in community meetings for planning ecoagriculture?" Possible responses were "yes", "no" and "not sure / neutral." An overwhelming 94.7\% of the responses were "yes", $1.2 \%$ were "no" and $4.1 \%$ "neutral." This result shows that most farmers were willing to participate in the proposed initiative. This outcome demonstrates communal farmers' eagerness to invest in innovations that aim to improve crop yields, livelihoods, income levels and living standards. The overwhelming positive response may however be reflective of the farmers' interest in outside help rather than commitment to participation in ecoagriculture per se. The farmers were probably eager to participate in projects and programmes perceived as offering some kind of financial benefit or subsidised inputs.

\section{Unique Opportunities Towards Ecoagriculture Within a TFCA}

Several conditions largely related to the MTA's geographical location made planned ecoagriculture highly feasible.

i. The location of MTA in a biodiversity hotspot (Van Wyk and Smith, 2001) means that ecoagriculture initiatives are highly likely to attract local and international players prepared to support innovations that promote biodiversity conservation.

ii. "TFCAs are well supported at high political levels, helping to generate much funding for development and conservation projects" (Smith et al., 2008:3). The Governments of South Africa, Mozambique and Swaziland were committed to invest substantially in the Lubombo TFCA. Interviews revealed that considerable technical and material support 
for community initiatives aimed at improving rural livelihoods as well as promoting biodiversity conservation in the TFCA was available from the local municipality and provincial government. This explains the high priority given to livelihoods and conservation and the lack of interest in agriculture among the stakeholders. The MTA had access to support and resources at local and higher levels that would not be available to a rural community outside of a TFCA.

iii. Mathenjwa community had a positive attitude towards conservation. This attitude was probably induced by awareness campaigns (by governmental and private organisations like the Department of Environmental Affairs and the Wildlands Conservation Trust respectively) when the area became a TFCA. The community set aside land for the Usuthu Gorge CCA towards in-situ conservation of natural vegetation and wildlife which demonstrates its support for biodiversity conservation programmes with livelihood-improving agendas.

iv. The area's biodiversity had not suffered major disturbance from human activity and its natural vegetation was almost pristine (Smith et al., 2008). The natural scenery (rolling landscape, mountains, gorges, and valleys), wildlife and a unique culture (a mix of Zulu, Swati and Tsonga cultures) could attract international and local visitors. Thus, forms of tourism showcasing rural lifestyle, art, culture and heritage at rural locations collectively known as rural tourism (Mader, 2009) could be developed.

v. Agriculture alone could not provide adequate livelihoods given the area's dryness and low production potential. Ecoagriculture presents opportunities for alternative income sources and diversified livelihoods. Examples are rural tourism, product or landscape certification and payments for environmental services whereby local farmers are paid in 
exchange for managing their land to provide ecological services like watershed protection and carbon sinks (Engel et al. 2008).

The combination of a TFCA infrastructure and a relatively arid environment strongly support the implementation of ecoagriculture at a community level. This leaves several ways in which the community can choose to expand ecoagriculture. Despite the above positive conditions, the initiative to develop planned and systematically managed ecoagriculture systems in the MTA faces challenges. A critical shortage of water for household and agricultural uses, poor transport and marketing facilities, lack of relevant knowledge or skills and lack of access to credit facilities, all work against the initiative.

The farmers had no title deeds over the land they occupied, a factor that discourages on-farm investment into non-farm income generating activities (Fraser, 2003). Interviews with local farmers revealed that the farmers wanted title deeds as a form of collateral security when borrowing capital. However, the farmers generally felt that their access to land was guaranteed and lack of title deeds was not a major barrier against ecoagriculture implementation. A similar finding was made among communal farmers in Zimbabwe and it was concluded that peasant farmers had confidence in the communal land tenure system (Chitakira and Torquebiau, 2010). This situation brightens the prospects of implementing ecoagriculture although there may always be uncertainties relating to the success of any new innovation.

Although ecoagriculture was seen as an appropriate development for the MTA based on stakeholder perceptions, local farmers had their priority needs. Access to clean water, jobs, food, 
farming equipment, inputs and better health services had higher priority than ecoagriculture per se. The farmers' perceptions of systematic ecoagriculture as a possible conduit for satisfying these needs probably contributed to the overwhelming willingness to implement the initiative. It would be recommendable therefore to start with ecoagriculture strategies that will have a noticeable effect on local priority needs. For instance, certain agroforestry technologies contribute to soil fertility improvement enabling higher crop yields, important for improved food security. Agroforestry technologies offer many advantages particularly on the plateau where the problems of dwindling soil fertility, woody cover and pastures are more critical. The undulating landscapes and mountainous terrain of the MTA present opportunities for commercial hiking, biking, horse riding, scenic viewing and camping. Bird watching and game viewing in the local Usuthu Gorge CCA present further opportunities for rural tourism. If such activities could be managed by individuals from the community, tourism management would become part of the farmers' calendar. It is recognised that CBNRMPs often experience the problem of elite capture (McGahey et al., 2007) and wealthy groups of villagers that already have assets to support tourism and conservation are more likely to benefit. However, it depends on how the CBNRMPs are organised, particularly how the controlling power is shared. The earlier phases of CAMPFIRE and ADMADE in Zimbabwe and Zambia respectively have shown that under good governance CBNRMPs have the capacity to benefit local communities economically and socially (Rodary, 2009). On the other hand, elite villagers can play key roles in facilitating the success of community-based initiatives. Ecoagriculture innovations involving rural tourism, processing and marketing resources occurring in abundance in the MTA such as amarula fruit (Sclerocarya birrea), Aloe marlothii and some medicinal plants, could generate employment and bring offfarm income to the farmers thereby alleviating poverty. Such developments would require that 
the community becomes actively involved in decision-making about the particular strategies of ecoagriculture they would like to pursue.

\section{CONCLUSION}

The research establishment in agriculture has focused on a single question about how to maximise production (Perfecto et al., 2009). Attention should shift towards strategies for balancing biodiversity conservation and food production at the landscape level. The present study contributes to this regard through analysing ecoagriculture stakeholders in a TFCA context. Successful implementation of ecoagriculture requires effective stakeholder collaboration and this makes stakeholder analysis on a specific-area basis essential. This study has shown that ecoagriculture stakeholders for a TFCA smallholder community are multiple and diverse. With varying degrees of influence and importance, virtually all individuals or institutions with an interest in a community's biophysical and socio-cultural aspects have a stake in ecoagriculture. Ecoagriculture extension workers and other players who would facilitate ecoagriculture planning and implementation need to be well-informed about key stakeholders in order to make a careful selection of the parties to engage.

The initiative to systematically manage ecoagriculture in smallholder communities was welcomed by stakeholders and appreciated as a sustainable way to address existing environmental challenges. Since ecoagriculture is a broad package that can address both immediate and long term needs, the selection of appropriate strategies is necessary. Ecoagriculture strategies that address urgent local priority needs should be promoted until it becomes viable to invest in strategies that yield economic and environmental returns in the 
longer term. Potential challenges to the proposed initiative are a cause for concern. However, with enough stakeholder commitment to dealing with the challenges, systematically managed production-with-protection strategies could become a reality in the study area and hopefully in other communities elsewhere under comparable conditions.

Further research could focus on visioning or formulation of future scenarios regarding ecoagriculture innovations, and on possibilities of adding value through initial processing and certification of local resources as livelihood transforming measures.

\section{Acknowledgements}

This work was supported by the National Research Foundation (South Africa), CIRAD (France), the International Foundation for Science (IFS), the French Institute of South Africa (IFAS) and the University of Pretoria. Ezemvelo-KZN Wildlife and the Wildlands Conservation Trust provided critical logistical support for which we are very thankful. The cooperation of the Mathenjwa community and all who offered their valuable time and effort during interviews and meetings is highly appreciated.

\section{REFERENCES}

Bellefontaine, R., et al. 2002. Trees outside forests: towards better awareness. Rome: CIRAD, FAO.

Blair, J. D., \& Fottler, M. D. 1990. Challenges in health care management: strategic perspectives for managing key stakeholders. San Francisco: Jossey-Bass Publishers. 
Bourne, L. 2008. Stakeholder relationship management maturity, PMI Global Congress, 19-21 May, St Julians, Malta. http://www.stakeholdermapping.com/PDFs/SRMM_Paper.pdf

Buck, L. E., et al. 2006. Understanding ecoagriculture: a framework for measuring landscape performance. Ecoagriculture Discussion Paper No. 2. Washington, DC: Ecoagriculture Partners.

Chitakira, M., \& Torquebiau, E. 2010. Towards balancing production and protection: participatory landscape performance assessment in Kwazulu-Natal, South Africa. Paper presented at the ISDA 2010 Conference, 28-30 June, Montpellier.

Department of Sustainability and Environment, 2008. Stakeholder analysis. The State of Victoria: The Department of Sustainability and Environment.

Ecoagriculture Partners \& IUCN, 2007. Principles of engagement with stakeholders in negotiating and measuring landscape-level outcomes. New York: Ecoagriculture Working Group, Cornell University.

Ecoagriculture Partners, 2008. Applying the ecosystem approach to biodiversity conservation in agricultural landscapes. Ecoagriculture Policy Focus 1(1). http://www.ecoagriculture.org

Ecoagriculture Partners, 2008a. Engaging stakeholders. Landscape Measures Resource Centre. http://treadwell.ace.cornell.edu/ecoag1a/?p=11

Engel, S., et al. 2000. Designing payments for environmental services in theory and practice: An overview of the issues. Ecological Economics 65:663-674.

Eriksen, S. E. H., \& Watson, H. K. 2009. The dynamic context of southern african savannas: investigating emerging threats and opportunities to sustainability. Environmental Science and Policy 12:5-22. 
Evans, K., et al. 2006. Field guide to the future: Four ways for communities to think ahead. Nairobi: Centre for International Forestry Research (CIFOR), ASB, World Agroforestry Centre.

Fraser, G. 2003. Obstacles to agricultural development in the communal areas of the Eastern

Cape. Report for the Eastern Cape Provincial Growth and Development Plan, Addendum. Bhisho: Eastern Cape Provincial Government.

Grimble, R. 1998. Stakeholder methodologies in natural resource management. Wallingford: Natural Resources Institute.

Herselman, M. E. 2003. ICT in rural areas in South Africa: various case studies. InSITE -Where Parallels Intersect. June issue: 945-955.

ICRA, c.2001. Stakeholder matrices guidelines. ICRA learning materials. Wageningen: International Centre for Development Oriented Research in Agriculture.

Ingonyama Trust Board, 2004. The Ingonyama Trust Board: Presentation to the Portfolio Committee on the Activities of the Board. Pietermaritzburg: Ingonyama Trust.

Jozini Local Municipality, 2009. Integrated Development Plan Review 2008/2009. Pietermaritzburg: Jozini Local Municipality.

Lindenmayer, D., et al. 2008. A checklist for ecological management of landscapes for conservation. Ecology Letters 11:78-91.

$\begin{array}{lllll}\text { Mader, } & \text { R. } 2009 . & \text { Tourism }\end{array}$ http://www.planeta.com/ecotravel/tour/definitions.html

McGahey, D., Sallu, S. \& Sachedina, H. 2007. How does environmental governance affect the poor? Global and local forces shaping poverty alleviation in Africa. Report of the 
NERC/ESRC funded African Environments Programme Workshop. Oxford: Centre for the Environment, Oxford University.

Millennium Ecosystem Assessment, 2005. Ecosystems and human well-being: current state and trends. Volume 1. Washington / Covelo / London: Island Press.

Mucina, L., \& Rutherford, M.C. 2006. The vegetation of South Africa, Lesotho and Swaziland. Pretoria: South African National Biodiversity Institute.

Nakaggwa, F., 2009. Farming systems and ecosystem services analysis: towards ecoagriculture landscape. A case of Mathenjwa landscape, KwaZulu-Natal Province, South Africa. MSc Thesis. Montpellier SupAgro and University of Copenhagen.

Nemarundwe, N., et al. 2003. Future scenarios as an instrument for forest management: manual for training facilitators of future scenarios. Jakarta: CIFOR.

Perfecto, I., Vandermeer, J. \& Wright, A. 2009. Nature's matrix: linking agriculture, conservation and food sovereignty. London: Earthscan Publications Limited.

Pretty, J. 2008. Agricultural sustainability: concepts, principles and evidence. Philosophical Transactions of the Royal Society: Biological Sciences 363:447-465.

Republic of South Africa, 2004. National Environmental Management: Biodiversity Act, No. 10 of 2004 .

Rodary, E. 2009. Mobilizing for nature in southern African community-based conservation policies, or the death of the local. Biodivers Conserv 18:2585-2600.

SADC 1999. Protocol on wildlife conservation and law enforcement. Gaborone: SADC.

SADC 2006. SADC Transfrontier Conservation Areas (TFCAs). Gaborone: Food, Agriculture and Natural Resources Directorate. 
Sandwith, T. et al. 2001. Transboundary protected areas for peace and co-operation. Gland: IUCN.

Sayer, J., \& Campbell, B. 2004. The science of sustainable development: local livelihoods and the global environment. Cambridge: Cambridge University Press.

Scherr, S. J., \& McNeely, J. A. 2007. The challenge for ecoagriculture. In: Farming with nature: the science and practice of ecoagriculture, ed. S. J. Scherr, \& J. A. McNeely, 1-16. Washington, DC: Island Press.

Scherr, S. J., \& McNeely, J. A. 2008. Biodiversity conservation and agricultural sustainability: towards a new paradigm of 'ecoagriculture' landscapes. Philosophical Transactions of the Royal Society 363:477- 494.

Scherr, S. J., et al. 2011. Scaling-up landscape investment approaches in Africa: where do private market incentives converge with landscape restoration goals? Background paper for the Investment Forum on mobilizing investment in trees and landscape restoration. Washington DC: EcoAgriculture Partners and Program on Forests.

Schmeer, K. 2000. Stakeholder Analysis Guidelines, Section 2 of Policy Toolkit for Strengthening Health Reform. Washington DC: Partners for Health Reform.

Shames, S., \& Scherr, S. J. 2009. Agriculture and the convention on biological diversity: guidelines for applying the ecosystem approach. Ecoagriculture Discussion Paper No. 4. Washington DC: Ecoagriculture Partners.

Smith, R.J. et al. 2008. Designing a transfrontier conservation landscape for the Maputaland centre of endemism using biodiversity, economic and threat data. Biological Conservation 141:2127-2138. 
Soto, B. Munthali, S. M. \& Breen, C. 2001. Perceptions of the forestry and wildlife policy by the local communities living in the Maputo Elephant Reserve, Mozambique. Biodiversity and Conservation 10:1723-1738.

The World Bank. 2002. Building a sustainable future: the African region environment strategy. Washington, D.C.: The International Bank for Reconstruction and Development.

Triegaardt, J. D. 2006. Reflections on poverty and inequality in South Africa: policy considerations in an emerging democracy. Paper presented at the annual Association of South African Social Work Education Institutions (ASASWEI) conference organised by University of Venda Department of Social Work. 18-20 September 2006.

Van Oosterhout, S. 2005. Excerpts from Zimbabwe's communal areas. Ottawa: The International Development Research Centre.

Van Wyk, A. E., \& Smith, G. F. 2001. Regions of floristic endemism in Southern Africa: A review with emphasis on succulents. Pretoria: Umdaus Press. 